Kuchma Igor L., Gozhenko Anatoliy I., Flyunt Igor-Severyn S., Ruzhylo Sofiya V., Zukow Walery, Popovych Igor L. Immunotropic effects of nitrogenous metabolites in patients with chronic pyelonephritis. Journal of Education, Health and Sport. 2021;11(6):217226. eISSN 2391-8306. DOI http://dx.doi.org/10.12775/JEHS.2021.11.06.024

https://apcz.umk.pl/czasopisma/index.php/JEHS/article/view/JEHS.2021.11.06.024

https://zenodo.org/record/5091262

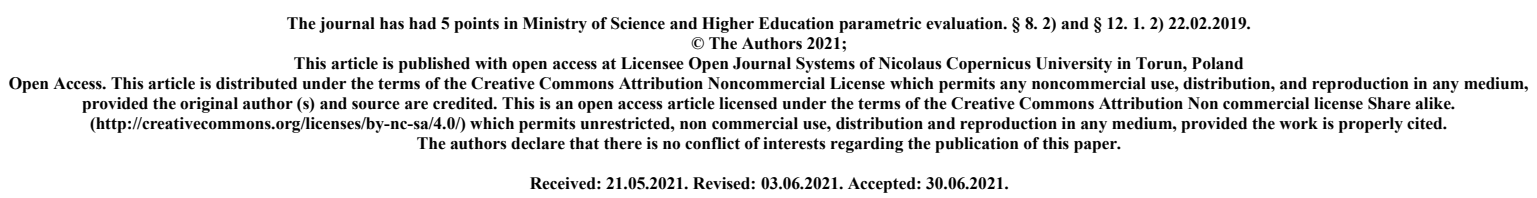

\title{
IMMUNOTROPIC EFFECTS OF NITROGENOUS METABOLITES IN PATIENTS WITH CHRONIC PYELONEPHRITIS
}

\author{
Igor L. Kuchma', Anatoliy I. Gozhenko' ${ }^{1}$ Igor-Severyn S. Flyunt ${ }^{2}$, Sofiya V. Ruzhylo ${ }^{2}$, \\ Walery Zukow ${ }^{3}$, Igor L. Popovych ${ }^{1,4}$ \\ ${ }^{1}$ Ukrainian Scientific Research Institute for Medicine of Transport, Odesa, Ukraine \\ igorkuchma@ukr.net; prof.gozhenko@gmail.com; \\ ${ }^{2}$ Ivan Franko Pedagogical University, Drohobych, Ukraine doctor-0701@ukr.net \\ ${ }^{3}$ Nicolaus Copernicus University, Torun, Poland w.zukow@wp.pl \\ ${ }^{4}$ Bohomolets' OO Institute of Physiology of National Academy of Sciences, Kyïv, \\ Ukraine i.popovych@biph.kiev.ua
}

\begin{abstract}
Background. We have previously shown that nitrogenous metabolites have immunomodulatory effects in healthy rats and humans as well as in patients with encephalopatia. The purpose of this study is their immunotropic activity in patients with chronic pyelonephritis. Materials and Methods. The object of observation were 24 men (aged 23-76 years) with chronic pyelonephritis in remission. The plasma levels and urinary excretion of uric acid, urea and creatinine and parameters of immunity twice (on admission and after 10 days of balneotherapy at the Truskavets' Spa) was performed. Results. Judging by the multiple correlation coefficient uricemia exhibits maximal immunotropic activity $(\mathrm{R}=0,772)$, followed by creatininemia $(\mathrm{R}=0,643)$, urea plasma $(\mathrm{R}=0,584)$ and creatinineuria $(\mathrm{R}=0,506)$ instead, urea and uric acid excretion correlate with immune parameters insignificantly $(\mathrm{R}=0,327$ and 0,262 respectively). Nitrogenous metabolites together upregulate most parameters of phagocytosis by neutrophils Staph. aureus and E. coli, the level in the blood of CD8 T-lymphocytes, CIC, IgM, componentes of leukocytogram as well as entropy of leukocytogram and immunocytogram. Instead, they downregulate the relative level of lymphocytes in general and of CD4 T-lymphocytes in particular. Conclusion. Nitrogenous metabolites exhibit immunotropic activity in both healthy humans and in patients with chronic pyelonephritis in remission. Both common and distinctive features of immunomodulation were revealed.
\end{abstract}

Key words: urea, uric acid, creatinine, immunity, relationships, healthy humans and patients. 


\section{INTRODUCTION}

We have previously shown that nitrogenous metabolites have immunomodulatory effects, both in healthy rats $[3,4,16]$ and humans [10] as well as in patients with encephalopatia [9]. With regard to uric acid, it is known that the magnitude and even the sign of the correlation coefficients with the parameters of the human body depend on the state of adaptation, the presence or absence of chronic pyelonephritis, as well as its phase [5-7,18]. Therefore, the aim of this study is immunotropic activity of nitrogenous metabolites in patients with chronic pyelonephritis.

\section{MATERIAL AND METHODS}

The object of observation were 27 men (aged 23-76 years) with chronic pyelonephritis in remission. The plasma and urinary levels of uric acid (by uricase method), urea (by urease method by reaction with phenolhypochlorite) and creatinine (by Jaffe's color reaction by Popper's method) and parameters of immunity twice (on admission and after 10 days of balneotherapy at the Truskavets' Spa) was performed.

The biochemic analyzes were carried out according to the instructions described in the manual [2]. The analyzers "Pointe-180" ("Scientific", USA) and "Reflotron" (Boehringer Mannheim, BRD) were used with appropriate sets.

Immune status evaluated on a set of I and II levels recommended by the WHO as described in the manuals [11,12]. For phenotyping subpopulations of lymphocytes used the methods of rosette formation with sheep erythrocytes on which adsorbed monoclonal antibodies against receptors CD3, CD4, CD8, CD22 and CD56 from company "Granum" (Kharkiv) with visualization under light microscope with immersion system. Subpopulation of $\mathrm{T}$ cells with receptors high affinity (T-active) determined by test of "active" rosette formation. The state of humoral immunity judged by the concentration in serum of Circulating Immune Complexes (by polyethylene glycol precipitation method) and Immunoglobulins classes M, G, A (ELISA, analyser "Immunochem", USA). In addition, the level of IL-1 was determined (by the ELISA with the use of analyzer "RT-2100C" and corresponding set of reagents from "Diactone", France).

The set of immune parameters of saliva was IgG, IgA, secretory IgA (ELISA, analyser "Immunochem", USA) and Lysozyme. The activity of the latter was evaluated by the bacteriolysis test Micrococcus lysodeicticus (nephelometric method) [8,15].

Parameters of phagocytic function of neutrophils estimated as described by SD Douglas and PG Quie [1] with moderately modification by MM Kovbasnyuk [6]. The objects of phagocytosis served daily cultures of Staphylococcus aureus (ATCC N 25423 F49) as typical specimen for Gram-positive Bacteria and Escherichia coli (O55 K59) as typical representative of Gram-negative Bacteria. Both cultures obtained from Laboratory of Hydro-Geological Regime-Operational Station JSC "Truskavets'kurort". Take into account the following parameters of Phagocytosis: activity (percentage of neutrophils, in which found microbes Hamburger's Phagocytic Index PhI), intensity (number of microbes absorbed one phagocytes - Microbial Count MC or Right's Index) and completeness (percentage of dead microbes Killing Index KI). On the basis of the recorded partial parameters of Phagocytosis, taking into account the Neutrophils $(\mathrm{N})$ content of 1 L blood, we calculated the integral parameter Bactericidal Capacity of Neutrophils (BCCN) by the formula [15]:

$\operatorname{BCCN}\left(10^{9} \mathrm{Bact} / \mathrm{L}\right)=\mathrm{N}\left(10^{9} / \mathrm{L}\right) \cdot \mathrm{PhI}(\%) \cdot \mathrm{MC}(\mathrm{Bact} / \mathrm{Phag}) \cdot \mathrm{KI}(\%) \bullet 10^{-4}$ 
In portion of capillary blood we counted up Leukocytogram (LCG) (Eosinophils, Rodshaped and Polymorphonucleary Neutrophils, Lymphocytes and Monocytes). On the basis of these elements, IL Popovych's Strain and Adaptation indices were calculated [13].

We calculated also the Entropy (h) of Immunocytogram (ICG) and Leukocytogram (LCG) using IL Popovych's formulas $[13,14]$ derived from classical CE Shannon's formula [17]: $\mathrm{hICG}=-\left[\mathrm{CD} 4 \bullet \log _{2} \mathrm{CD} 4+\mathrm{CD} 8 \bullet \log _{2} \mathrm{CD} 8+\mathrm{CD} 22 \cdot \log _{2} \mathrm{CD} 22+\mathrm{CD} 56 \bullet \log _{2} \mathrm{CD} 56\right] / \log _{2} 4$ $\mathrm{hLCG}=-\left[\mathrm{L} \cdot \log _{2} \mathrm{~L}+\mathrm{M} \bullet \log _{2} \mathrm{M}+\mathrm{E} \bullet \log _{2} \mathrm{E}+\mathrm{PMNN} \bullet \log _{2} \mathrm{PMNN}+\mathrm{RSN} \bullet \log _{2} \mathrm{RSN}\right] / \log _{2} 5$

Results processed by using the software package "Statistica 64".

\section{RESULTS AND DISCUSSION}

Following the accepted algorithm, we first created a matrix of correlations between nitrogenous metabolites and immune parameters (Table 1).

In the next step of the analysis, a regression model was constructed for each nitrogenous metabolite by stepwise exclusion until the maximum level of adjusted $\mathrm{R}^{2}$ was reached.

As expected, based on the previous results, uric acid showed the maximum immunotropic activity among nitrogenous metabolites (Table 2). 
Table 1. Matrix of correlations between nitrogenous metabolites and immunity parameters in patients with chronic pyelonephritis

\begin{tabular}{|c|c|c|c|c|c|c|}
\hline \multirow[b]{2}{*}{ Variable } & \multicolumn{6}{|c|}{ Correlations $(n=48)$} \\
\hline & $\mathrm{CrP}$ & UAP & CrE & UAE & Urea $\mathrm{E}$ & Urea P \\
\hline $\mathrm{Cr} P$ & 1,00 & 0,07 & $-0,33$ & $-0,23$ & $-0,23$ & 0,51 \\
\hline UA P & 0,07 & 1,00 & 0,08 & $-0,14$ & $-0,01$ & 0,00 \\
\hline $\mathrm{CrE}$ & $-0,33$ & 0,08 & 1,00 & 0,32 & 0,46 & $-0,07$ \\
\hline UAE & $-0,23$ & $-0,14$ & 0,32 & 1,00 & 0,68 & 0,12 \\
\hline Urea E & $-0,23$ & $-0,01$ & 0,46 & 0,68 & 1,00 & 0,11 \\
\hline Urea P & 0,51 & 0,00 & $-0,07$ & 0,12 & 0,11 & 1,00 \\
\hline IL-1 & $-0,00$ & $-0,38$ & 0,09 & $-0,06$ & $-0,05$ & 0,11 \\
\hline SlgA & 0,08 & 0,06 & 0,19 & $-0,09$ & $-0,19$ & $-0,04$ \\
\hline IgG Saliva & $-0,09$ & $-0,13$ & 0,03 & $-0,01$ & 0,09 & $-0,12$ \\
\hline Lysoz Sal & 0,02 & 0,02 & 0,15 & $-0,17$ & $-0,28$ & $-0,09$ \\
\hline IgA Saliva & $-0,03$ & $-0,17$ & 0,13 & $-0,05$ & $-0,17$ & $-0,10$ \\
\hline Phl vs St al & 0,06 & 0,37 & 0,06 & $-0,17$ & $-0,05$ & $-0,32$ \\
\hline MC St aur & 0,05 & 0,40 & 0,05 & $-0,17$ & 0,01 & $-0,34$ \\
\hline Killing St au & $-0,33$ & 0,26 & 0,23 & $-0,00$ & 0,13 & 0,04 \\
\hline Phl E coli & 0,11 & 0,24 & 0,04 & $-0,14$ & $-0,29$ & $-0,08$ \\
\hline FNE & 0,04 & 0,34 & $-0,00$ & $-0,05$ & 0,11 & $-0,30$ \\
\hline IKE & $-0,21$ & 0,32 & 0,06 & $-0,05$ & 0,04 & 0,07 \\
\hline $\mathrm{HL}$ & 0,33 & 0,21 & 0,08 & 0,00 & 0,12 & 0,20 \\
\hline BCA & $-0,24$ & 0,36 & 0,24 & 0,03 & 0,15 & $-0,18$ \\
\hline BCE & $-0,25$ & 0,44 & 0,14 & 0,06 & 0,15 & $-0,12$ \\
\hline LEU & 0,15 & 0,13 & $-0,05$ & 0,12 & 0,10 & 0,11 \\
\hline SNN & $-0,36$ & $-0,10$ & 0,24 & 0,14 & 0,09 & $-0,15$ \\
\hline BNN & 0,15 & 0,02 & 0,24 & 0,10 & 0,13 & 0,11 \\
\hline EO & 0,24 & 0,18 & $-0,06$ & $-0,01$ & 0,14 & 0,31 \\
\hline MON & $-0,02$ & 0,27 & 0,21 & 0,04 & 0,03 & $-0,15$ \\
\hline L\% & 0,32 & 0,00 & $-0,32$ & $-0,17$ & $-0,15$ & 0,11 \\
\hline INL & $-0,15$ & 0,05 & 0,15 & $-0,16$ & $-0,13$ & $-0,11$ \\
\hline INL2 & 0,08 & 0,12 & 0,01 & $-0,14$ & $-0,03$ & 0,21 \\
\hline IAP & $-0,35$ & $-0,09$ & 0,16 & 0,12 & $-0,05$ & $-0,26$ \\
\hline IAP2 & $-0,25$ & 0,01 & 0,21 & 0,04 & $-0,04$ & $-0,27$ \\
\hline TH & $-0,06$ & $-0,28$ & 0,04 & 0,11 & 0,03 & $-0,05$ \\
\hline TS & $-0,05$ & 0,40 & $-0,19$ & 0,09 & 0,08 & $-0,11$ \\
\hline CD22 & $-0,27$ & $-0,05$ & $-0,12$ & 0,09 & $-0,02$ & $-0,08$ \\
\hline TA & 0,08 & $-0,03$ & $-0,11$ & 0,15 & $-0,09$ & 0,00 \\
\hline $\mathrm{ClC}$ & $-0,15$ & 0,21 & 0,10 & 0,06 & $-0,03$ & $-0,02$ \\
\hline IGG & $-0,22$ & $-0,08$ & 0,17 & 0,04 & $-0,08$ & $-0,13$ \\
\hline IGA & 0,18 & 0,11 & 0,12 & 0,11 & $-0,11$ & 0,04 \\
\hline IGM & $-0,08$ & 0,08 & $-0,07$ & $-0,15$ & $-0,14$ & $-0,19$ \\
\hline CD56L & 0,08 & $-0,18$ & 0,15 & $-0,16$ & $-0,09$ & 0,13 \\
\hline $\mathrm{OL}$ & 0,29 & 0,08 & 0,13 & $-0,15$ & $-0,01$ & 0,11 \\
\hline HIM & $-0,33$ & 0,04 & $-0,07$ & 0,11 & 0,02 & $-0,14$ \\
\hline
\end{tabular}


Uricemia upregulates two parameters of phagocytosis of gram-positive and gram-negative bacteria by neutrophils as well as levels of CIC and theophilline sensitive T-lymphocytes while downregulates level og theophilline resistance T-lymphocytes. Degree of determination of uricemia immune status is $60 \%$ (Table 2 and Fig. 1).

Table 2. Regression Summary for Uricemia, $\boldsymbol{\mu M} / \mathrm{L}$ $\mathrm{R}=0,772 ; \mathrm{R}^{2}=0,596 ;$ Adjusted $\mathrm{R}^{2}=0,536 ; \mathrm{F}_{(6,4)}=10,1 ; \mathrm{p}<10^{-5}$

\begin{tabular}{|c|c|c|c|c|c|c|c|}
\hline & & Beta & $\begin{array}{l}\text { St. Err. } \\
\text { of Beta }\end{array}$ & B & $\begin{array}{l}\text { SE } \\
\text { of B }\end{array}$ & $t_{(41)}$ & $\begin{array}{l}\text { p- } \\
\text { level }\end{array}$ \\
\hline Varial & $\mathrm{r}$ & & Intercpt & $-2,552$ & 0,714 & $-3,57$ & 0,001 \\
\hline Bactericidal & 0,44 & 0,282 & 0,107 & 0,0008 & 0,0003 & 2,64 & 0,012 \\
\hline $\mathrm{CD8}^{+} \mathrm{T}$-cytoly & 0,40 & 0,323 & 0,109 & 0,0056 & 0,0019 & 2,96 & 0,005 \\
\hline Phagocytose Index vs Staph. aureus, \% & 0,37 & 0,354 & 0,107 & 0,0245 & 0,0074 & 3,31 & 0,002 \\
\hline CIC Serum, units & 0,21 & 0,207 & 0,103 & 0,0011 & 0,0005 & 2,02 & 0,050 \\
\hline Entropy of Leukocytogram & 0,21 & 0,283 & 0,106 & 0,6336 & 0,2367 & 2,68 & 0,011 \\
\hline CD4 $^{+}$T-helper Lymphocytes, $\%$ & $-0,28$ & $-0,394$ & 0,108 & $-0,0070$ & 0,0019 & $-3,63$ & 0,001 \\
\hline
\end{tabular}

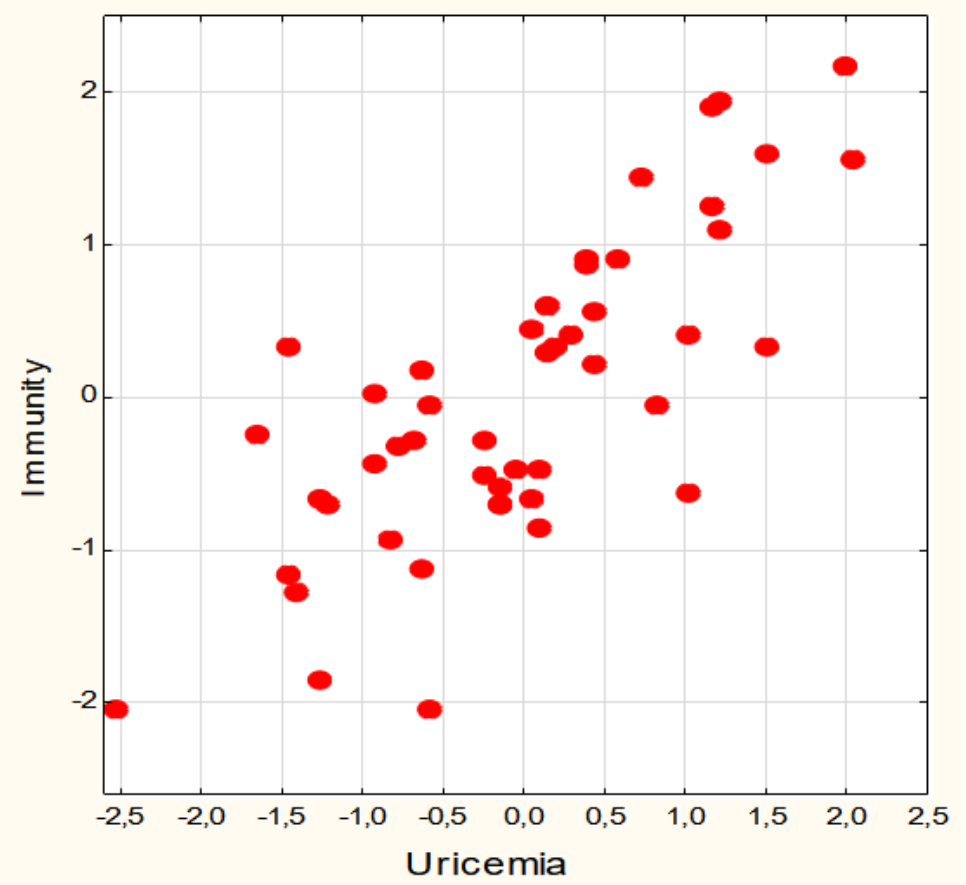

$\mathrm{R}=0,772 ; \mathrm{R}^{2}=0,596 ; \chi_{(6)}^{2}=39 ; \mathrm{p}<10^{-6} ; \Lambda$ Prime $=0,404$

Fig. 1. Scatterplot of canonical correlation between Uricemia (X-line) and the Immunity (Y-line) in patients with pyelonephritis

Instead, multiple correlation between uricosuria and immune parameters are insignificant (Table 3).

Table 3. Regression Summary for Uricosuria, $\mathbf{m M} / \mathbf{L}$

$\mathrm{R}=0,269 ; \mathrm{R}^{2}=0,072 ;$ Adjusted $\mathrm{R}^{2}=0,031 ; \mathrm{F}_{(2,45)}=1,75 ; \mathrm{p}=0,185$

\begin{tabular}{|l|l|l|l|l|l|l|l|}
\hline & & Beta & $\begin{array}{l}\text { St. Err. } \\
\text { of Beta }\end{array}$ & B & $\begin{array}{l}\text { SE } \\
\text { of B }\end{array}$ & $\mathrm{t}_{(45)}$ & $\begin{array}{l}\text { p- } \\
\text { level }\end{array}$ \\
\hline Variables & $\mathrm{r}$ & & Intercpt & 12,62 & 4,88 & 2,59 & 0,013 \\
\hline Lysozime Saliva, mg/L & $\mathbf{- 0 , 1 7}$ & $-0,216$ & 0,148 & $-0,039$ & 0,026 & $-1,46$ & 0,151 \\
\hline Pan-Lymphocytes, \% & $\mathbf{- 0 , 1 7}$ & $-0,217$ & 0,148 & $-0,045$ & 0,031 & $-1,47$ & 0,148 \\
\hline
\end{tabular}


Creatininemia, like uricemia, upregulates entropy of Leukocytogram as well as level of Lymphocytes, while downregulates the level of Neutrophils and its killing activity against gram-positive bacteria as well as two information parameters. Degree of determination of creatininemia immune status is $41 \%$ (Table 4 and Fig. 2).

Table 4. Regression Summary for Creatininemia, $\boldsymbol{\mu M} / \mathrm{L}$

$\mathrm{R}=0,643 ; \mathrm{R}^{2}=0,413 ;$ Adjusted $\mathrm{R}^{2}=0,327 ; \mathrm{F}_{(6,4)}=4,8 ; \mathrm{p}=0,0008$

\begin{tabular}{|l|l|l|l|l|l|l|l|}
\hline & & Beta & $\begin{array}{l}\text { St. Err. } \\
\text { of Beta }\end{array}$ & B & $\begin{array}{l}\text { SE } \\
\text { of B }\end{array}$ & $\mathbf{t}_{(41)}$ & $\begin{array}{l}\text { p- } \\
\text { level }\end{array}$ \\
\hline Variables & $\mathbf{r}$ & & Intercpt & $-268,6$ & 311,5 & $-0,86$ & 0,393 \\
\hline Polymorphonuclear Neutrophils, \% & $\mathbf{- 0 , 3 6}$ & 2,244 & 1,368 & 3,853 & 2,348 & 1,64 & 0,108 \\
\hline Popovych's Adaptation Index, units & $\mathbf{- 0 , 3 5}$ & $-0,460$ & 0,166 & $-9,275$ & 3,338 & $-2,78$ & 0,008 \\
\hline Killing Index vs Staph. aureus, \% & $\mathbf{- 0 , 3 3}$ & $-0,302$ & 0,128 & $-0,429$ & 0,182 & $-2,36$ & 0,023 \\
\hline Entropy of Immunocytogram & $\mathbf{- 0 , 3 3}$ & $-0,208$ & 0,134 & $-119,3$ & 76,71 & $-1,56$ & 0,128 \\
\hline Entropy of Leukocytogram & $\mathbf{0 , 3 3}$ & 0,902 & 0,465 & 280,6 & 144,7 & 1,94 & 0,059 \\
\hline Pan-Lymphocytes, \% & $\mathbf{0 , 3 2}$ & 1,918 & 1,120 & 3,447 & 2,013 & 1,71 & 0,094 \\
\hline
\end{tabular}

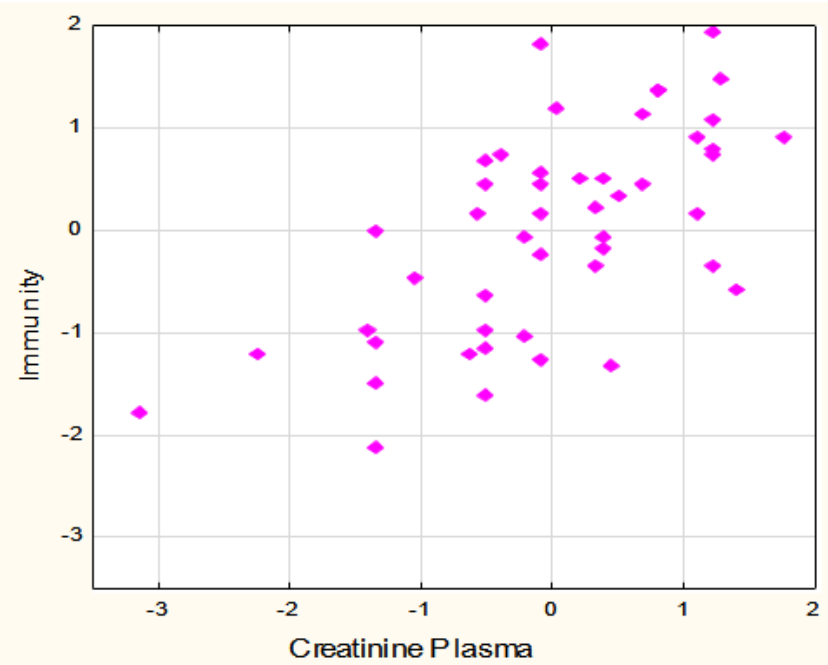

$\mathrm{R}=0,643 ; \mathrm{R}^{2}=0,413 ; \chi_{(6)}^{2}=23 ; \mathrm{p}=0,0008 ; \Lambda$ Prime $=0,587$

Fig. 2. Scatterplot of canonical correlation between Creatininemia ( $X$-line) and the Immunity (Y-line) in patients with pyelonephritis

The immunomodulatory activity of creatinineuria is weaker than that of creatininemia, but still significant (Table 5).

Table 5. Regression Summary for Creatinineuria, $\mathbf{m M} / \mathbf{L}$

$\mathrm{R}=0,506 ; \mathrm{R}^{2}=0,256 ;$ Adjusted $\mathrm{R}^{2}=0,147 ; \mathrm{F}_{(6,4)}=2,35 ; \mathrm{p}=0,049$

\begin{tabular}{|l|l|l|l|l|l|l|l|}
\hline & & Beta & $\begin{array}{l}\text { St. Err. } \\
\text { of Beta }\end{array}$ & B & $\begin{array}{l}\text { SE } \\
\text { of B }\end{array}$ & $\mathbf{t}_{(41)}$ & $\begin{array}{l}\text { p- } \\
\text { level }\end{array}$ \\
\hline Variables & $\mathrm{r}$ & & Intercpt & 0,077 & 7,44 & 0,01 & 0,992 \\
\hline Pan-Lymphocytes, \% & $\mathbf{- 0 , 3 2}$ & $-0,329$ & 0,168 & $-0,1696$ & 0,0865 & $-1,96$ & 0,057 \\
\hline Bactericidal Capacity vs St. aur, 10 $\mathbf{1 0}^{\mathbf{9}} \mathbf{B} / \mathbf{L}$ & $\mathbf{0 , 2 4}$ & $-0,280$ & 0,214 & $-0,0350$ & 0,0267 & $-1,31$ & 0,198 \\
\hline Rod-shaped Neutrophils, \% & $\mathbf{0 , 2 4}$ & 0,249 & 0,144 & 0,9491 & 0,5494 & 1,73 & 0,092 \\
\hline Killing Index vs Staph. aureus, \% & $\mathbf{0 , 2 3}$ & 0,315 & 0,169 & 0,1281 & 0,0687 & 1,86 & 0,069 \\
\hline Monocytes, \% & $\mathbf{0 , 2 1}$ & 0,255 & 0,149 & 0,5507 & 0,3218 & 1,71 & 0,095 \\
\hline Secretory IgA Saliva, mg/L & $\mathbf{0 , 1 9}$ & 0,168 & 0,152 & 0,0094 & 0,0085 & 1,11 & 0,275 \\
\hline
\end{tabular}


Immunotropic effect of urea was minimal among the studied nitrogenous metabolites (Tables 6 and 7, Fig. 3).

Table 6. Regression Summary for Urea Plasma, $\mathrm{mM} / \mathrm{L}$

$\mathrm{R}=0,584 ; \mathrm{R}^{2}=0,342 ;$ Adjusted $\mathrm{R}^{2}=0,280 ; \mathrm{F}_{(4,4)}=5,6 ; \mathrm{p}=0,0011$

\begin{tabular}{|l|l|l|l|l|l|l|l|}
\hline & & Beta & $\begin{array}{l}\text { St. Err. } \\
\text { of Beta }\end{array}$ & B & $\begin{array}{l}\text { SE } \\
\text { of B }\end{array}$ & $\mathbf{t}_{(43)}$ & $\begin{array}{l}\text { p- } \\
\text { level }\end{array}$ \\
\hline Variables & $\mathbf{r}$ & & Intercpt & 10,09 & 1,19 & 8,46 & $10^{-6}$ \\
\hline Microbial Count for St. aur., Bac/Phag & $\mathbf{- 0 , 3 4}$ & $-0,394$ & 0,132 & $-0,050$ & 0,017 & $-2,99$ & 0,005 \\
\hline Popovych's Adaptation Index, units & $\mathbf{- 0 , 2 6}$ & $-0,341$ & 0,130 & $-0,631$ & 0,240 & $-2,62$ & 0,012 \\
\hline IgM Serum, g/L & $\mathbf{- 0 , 1 9}$ & $-0,146$ & 0,132 & $-0,499$ & 0,448 & $-1,11$ & 0,272 \\
\hline Eosinophils, \% & $\mathbf{0 , 3 1}$ & 0,288 & 0,125 & 0,223 & 0,097 & 2,30 & 0,026 \\
\hline
\end{tabular}

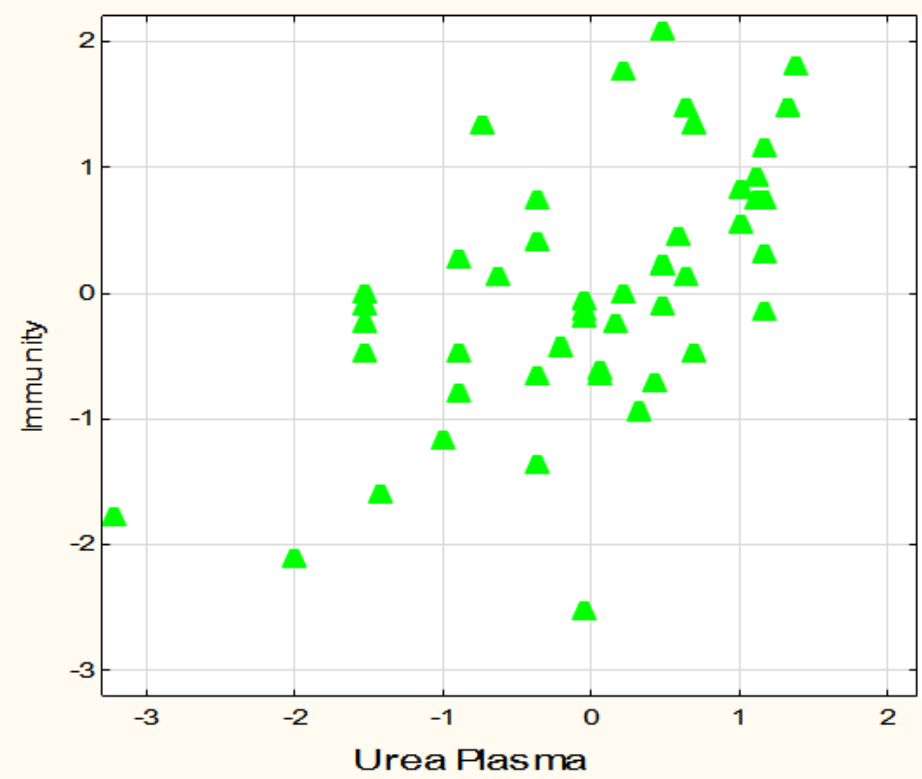

$\mathrm{R}=0,584 ; \mathrm{R}^{2}=0,342 ; \chi^{2}{ }_{(4)}=18 ; \mathrm{p}=0,001 ; \Lambda$ Prime $=0,658$

Fig. 3. Scatterplot of canonical correlation between Urea Plasma (X-line) and the Immunity (Y-line) in patients with pyelonephritis

Table 7. Regression Summary for Urea Excretion, $\mathbf{m M} / \mathbf{L}$

$\mathrm{R}=0,327 ; \mathrm{R}^{2}=0,107 ;$ Adjusted $\mathrm{R}^{2}=0,068 ; \mathrm{F}_{(2,45)}=2,70 ; \mathrm{p}=0,078$

\begin{tabular}{|l|l|l|l|l|l|l|l|}
\hline & & Beta & $\begin{array}{l}\text { St. Err. } \\
\text { of Beta }\end{array}$ & B & $\begin{array}{l}\text { SE } \\
\text { of B }\end{array}$ & $\mathrm{t}_{(45)}$ & $\begin{array}{l}\text { p- } \\
\text { level }\end{array}$ \\
\hline Variables & $\mathrm{r}$ & & Intercpt & 3711 & 1703 & 2,18 & 0,035 \\
\hline Phagocytose Index vs E. coli, \% & $\mathbf{- 0 , 2 9}$ & $-0,192$ & 0,163 & $-23,1$ & 19,7 & $-1,18$ & 0,246 \\
\hline Lysozime Saliva, mg/L & $\mathbf{- 0 , 2 8}$ & $-0,185$ & 0,163 & $-4,38$ & 3,86 & $-1,14$ & 0,262 \\
\hline
\end{tabular}

At the final stage, the canonical correlation between the parameters of nitrogenous metabolites, on the one hand, and the parameters of immunity, on the other hand, was analyzed. The program identified only one significant pair of canonical roots. Nitrogen root receives the maximum factor load from uricemia, much smaller, but unidirectional - from the 
excretion of creatinine and urea, and similar in strength, but opposite in sign - from their plasma levels (Table 8).

Table 8. Factor load on canonical roots of nitrogenous metabolites and immunity parameters in patients with chronic pyelonephritis

\begin{tabular}{|c|c|}
\hline Left set & Root \\
\hline Uric acid Plasma & 0,883 \\
\hline Creatinine Excretion & 0,305 \\
\hline Urea Excretion & 0,265 \\
\hline Uric acid Excretion & 0,024 \\
\hline Urea Plasma & $-0,320$ \\
\hline Creatinine Plasma & $-0,278$ \\
\hline Right set & Root \\
\hline Bactericidal Capacity vs E. coli, $10^{9} \mathrm{~B} / \mathrm{L}$ & $\mathbf{0 , 5 4 3}$ \\
\hline Microbial Count for Staph. aureus, Bac/Phag & 0,504 \\
\hline Bactericidal Capacity vs Staph. aur, $10^{9} \mathrm{~B} / \mathrm{L}$ & 0,496 \\
\hline Phagocytose Index vs Staph. aureus, \% & 0,250 \\
\hline CD8 $^{+}$T-cytolytic Lymphocytes, \% & 0,431 \\
\hline Killing Index vs Staph. aureus, \% & 0,340 \\
\hline Monocytes, \% & 0,322 \\
\hline CIC Serum, units & 0,226 \\
\hline Phagocytose Index vs E. coli, \% & 0,155 \\
\hline Entropy of Leukocytogram & 0,139 \\
\hline Entropy of Immunocytogram & 0,115 \\
\hline IgM Serum, g/L & 0,106 \\
\hline Eosinophils, \% & 0,092 \\
\hline Popovych's Adaptation Index, units & 0,022 \\
\hline Polymorphonuclear Neutrophils, \% & 0,018 \\
\hline Secretory IgA Saliva, mg/L & 0,017 \\
\hline Rod-shaped Neutrophils, \% & 0,009 \\
\hline CD4 $^{+}$T-helper Lymphocytes, \% & $-0,243$ \\
\hline Pan-Lymphocytes, \% & $-0,117$ \\
\hline Lysozime Saliva, mg/L & $-0,031$ \\
\hline
\end{tabular}

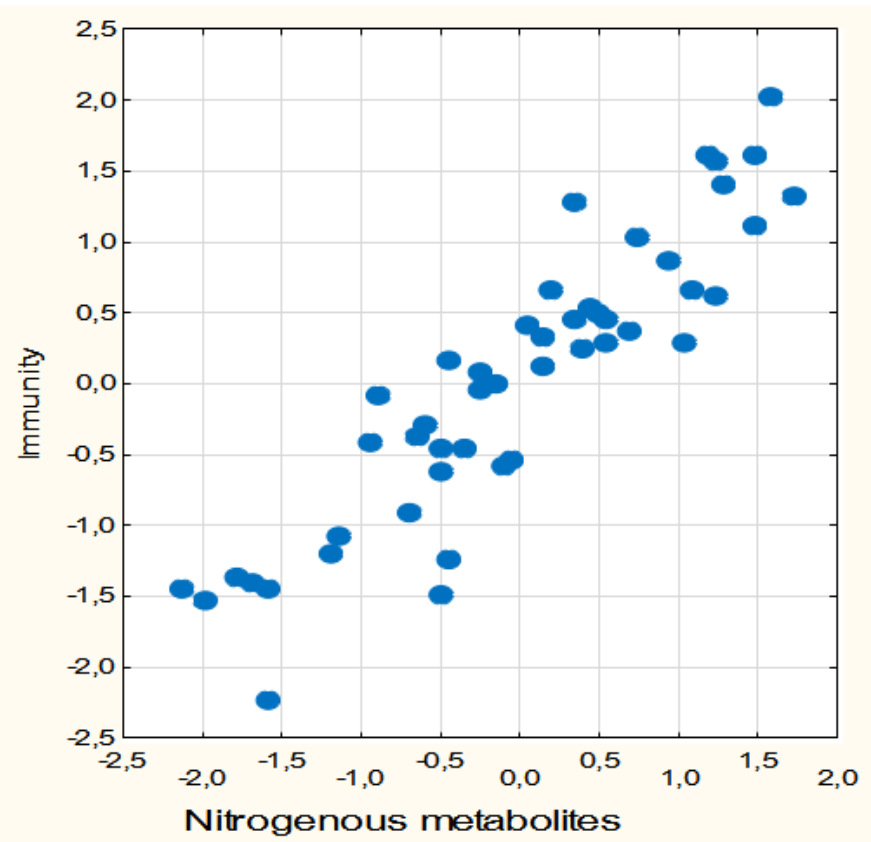

$\mathbf{R}=0,909 ; \mathbf{R}^{2}=0,827 ; \chi_{(120)}^{2}=170 ; p=0,0017 ; \Lambda$ Prime $=0,0062$

Fig. 4. Scatterplot of canonical correlation between Nitrogenous Metabolites (X-line) and the Immunity (Y-line) in patients with chronic pyelonephritis 
All but not three immune parameters are subject to upregulation. The degree of determination of the immune status of this sample of patients with nitrogenous metabolites is $83 \%$ (Fig. 4).

A more detailed analysis of this and previous samples in a comparative aspect will be the topic of the next article.

\section{ACKNOWLEDGMENT}

We express sincere gratitude to administration of clinical sanatorium "Moldova" for help in conducting this investigation.

\section{ACCORDANCE TO ETHICS STANDARDS}

Tests in patients are conducted in accordance with positions of Helsinki Declaration 1975 and directive of National Committee on ethics of scientific researches. During realization of tests from all participants the informed consent is got and used all measures for providing of anonymity of participants.

\section{REFERENCES}

1. Douglas SD, Quie PG. Investigation of Phagocytes in Disease. Churchil; 1981: 110 p.

2. Goryachkovskiy AM. Clinical Biochemistry [in Russian]. Odesa: Astroprint; 1998: 608 p.

3. Gozhenko AI, Smagliy VS, Korda IV, Badiuk NS, Zukow W, Popovych IL. Functional relationships between parameters of uric acid exchange and immunity in female rats. Actual problems of transport medicine. 2019; 4(58): 123-131.

4. Gozhenko AI, Smagliy VS, Korda IV, Badiuk NS, Zukow W, Popovych IL. Features of immune status in different states of uric acid metabolism in female rats. Journal of Education, Health and Sport. 2019; 9(12): 167-180.

5. Gozhenko AI, Smagliy VS, Korda IV, Badiuk NS, Zukow W, Kovbasnyuk MM, Popovych IL. Relationships between parameters of uric acid exchange and immunity as well as microbiota in patients with neuroendocrine-immune complex dysfunction. Journal of Education, Health and Sport. 2020; 10(1): 165-175.

6. Gozhenko AI, Smagliy VS, Korda IV, Badiuk NS, Zukow W, Kovbasnyuk MM, Popovych IL. Relationships between changes in uric acid parameters metabolism and parameters of immunity and microbiota in patients with neuroendocrine-immune complex dysfunction. Journal of Education, Health and Sport. 2020; 10(2): 212-222.

7. Ivassivka SV, Popovych IL, Aksentiychuk BI, Flyunt IS. Physiological Activity of Uric Acid and its Role in the Mechanism of Action of Naftussya Water [in Ukrainian]. Kyiv. Computerpress; 2004: $163 \mathrm{p}$.

8. Khaitov RM, Pinegin BV, Istamov KhI. Ecological Immunology [in Russian]. Moskva. VNIRO; 1995: $219 \mathrm{p}$.

9. Kuchma IL, Gozhenko AI, Bilas VR, Ruzhylo SV, Kovalchuk GY, Nahurna YV, Zukow W, Popovych IL. Immunotropic effects of nitrogenous metabolites (creatinine, urea, uric acid and bilirubin) in humans exposed to the factors of the accident at the Chornobyl nuclear power plant. Journal of Education, Health and Sport. 2020; 10(12): 314-331.

10. Kuchma IL, Gozhenko AI, Ruzhylo SV, Kovalchuk GY, Nahurna YV, Zukow W, Popovych IL. Immunotropic effects of nitrogenous metabolites in healthy humans. Journal of Education, Health and Sport. 2021; 11(5): 197-206.

11. Lapovets' LYe, Lutsyk BD. Handbook of Laboratory Immunology [in Ukrainian]. Kyïv. 2004: 173 p.

12. Perederiy VG, Zemskov AM, Bychkova NG, Zemskov VM. Immune status, principles of its evaluation and correction of immune disorders [in Russian]. Kyiv. Zdorovya; 1995: 211 p. 
13. Popadynets' OO, Gozhenko AI, Zukow W, Popovych IL. Relationships between the entropies of EEG, HRV, immunocytogram and leukocytogram. Journal of Education, Health and Sport. 2019; 9(5): 651-666.

14. Popovych IL. Information effects of bioactive water Naftyssya in rats: modulation entropic, prevention desynchronizing and limitation of disharmonizing actions water immersion stress for information components of neuro-endocrine-immune system and metabolism, which correlates with gastroprotective effect [in Ukrainian]. Medical Hydrology and Rehabilitation. 2007; 5(3): 50-70.

15. Popovych IL, Flyunt IS, Alyeksyeyev OI, Barylyak LG, Bilas VR. Sanogenetic Bases of Rehabilitation on Spa Truskavets' Urological Patients from Chornobylian Contingent [in Ukrainian]. Kyiv. Computerpress; 2003: 192 p.

16. Popovych IL, Gozhenko AI, Kuchma IL, Zukow W, Bilas VR, Kovalchuk GY, Ivasivka AS. Immunotropic effects of so-called slag metabolites (creatinine, urea, uric acid and bilirubin) at rats. Journal of Education, Health and Sport. 2020; 10(11): 320-336.

17. Shannon CE. A mathematical theory of information. Bell Syst Tech J. 1948; 27: 379-423.

18. Smagliy VS, Gozhenko AI, Korda IV, Badiuk NS, Zukow W, Kovbasnyuk MM, Popovych IL. Variants of uric acid metabolism and their immune and microbiota accompaniments in patients with neuroendocrine-immune complex dysfunction. Actual problems of transport medicine. 2020; 1(59): 114-125. 